\title{
Enkele inhoudelijke aspecten van KEI: waar gaat en waar moet het naartoe?
}

\author{
Verslag van de najaarsvergadering 2015 van de Nederlandse Vereniging voor Procesrecht
}

\author{
Mr.J.J. Dammingh en mr. L.M. vanden Berg*
}

\begin{abstract}
Algemeen
De najaarsvergadering van 2015 van de Nederlandse Vereniging voor Procesrecht (hierna: $\mathrm{NVvP}$ ), die plaatsvond op 27 november 2015, had als onderwerp enkele inhoudelijke aspecten van 'KEI' (Kwaliteit en Innovatie). De voorzitter, prof. mr. C.J.M. Klaassen, merkte in haar inleiding hierover het volgende op. Eerder is bij vergaderingen van de NVvP reeds aandacht aan het 'KEI-project' ${ }^{1}$ besteed (onder meer bij de najaarsvergadering 'Procesinnovatie: KEIgoede ideeën' van 2013). KEI heeft inmiddels geresulteerd in diverse wetsvoorstellen, die zich in een vergevorderd stadium van parlementaire behandeling bevinden: zowel wetsvoorstel 34059 (strekkend tot de vereenvoudiging en digitalisering van de procedure in eerste aanleg) als wetsvoorstel 34138 (aangaande het procesrecht in hoger beroep en cassatie) is reeds door de Tweede Kamer aanvaard. Beide voorstellen liggen nu bij de Eerste Kamer. In zijn brief aan de Eerste Kamer van 16 oktober 2015 heeft de minister van Veiligheid en Justitie geschreven dat het wetgevingstraject zich in 'de eindfase' bevindt. ${ }^{2}$
\end{abstract}

De inhoud van voornoemde - door de Tweede Kamer aanvaarde - wetsvoorstellen wordt bij deze vergadering als een 'vaststaand gegeven' beschouwd. (NB De wetsvoorstellen en het daarin vervatte vernieuwde procesrecht zullen in dit verslag gemakshalve 'de nieuwe wet' worden genoemd.) Bij het wetgevingsproces en ook in de literatuur heeft vooral de (beoogde) digitalisering van de rechtspraak in de belangstel-

\footnotetext{
Mr. J.J. Dammingh is universitair hoofddocent burgerlijk (proces)recht aan de Radboud Universiteit Nijmegen. Mr. L.M. van den Berg is senior juridisch medewerker in de rechtbank Gelderland en tevens verbonden aan de sectie burgerlijk (proces)recht van de Radboud Universiteit Nijmegen.

1. KEI (Kwaliteit en Innovatie) is het door de Raad voor de rechtspraak en de minister van Veiligheid en Justitie geïnitieerde project gericht op het behoud en de versterking van goede, toegankelijke, eenvoudige, snelle, doelmatige en betaalbare rechtspraak. Het project moet resulteren in een nieuwe, eenvoudige, begrijpelijke, flexibele, uniforme en digitale basisprocedure, waarin de rechter de regie voert, maatwerk levert en geschillen snel en definitief beslecht. Zie de brief van de minister van Veiligheid en Justitie van 11 juni 2013, Kamerstukken II 2012/13, 29279, 164, p. 2.

2. Brief van de minister van Veiligheid en Justitie van 16 oktober 2015, Kamerstukken I 2015/16, 34059 en 34138, C, p. 1-2.
}

ling gestaan. ${ }^{3}$ Er zal echter meer veranderen in het kader van het vernieuwde procesrecht.

De inhoud van de nieuwe wet als uitgangspunt nemend zal de nadruk bij deze vergadering liggen op (a) de mondelinge behandeling en (b) het leveren van 'maatwerk. ${ }^{4}$ De voorzitter merkt over deze 'speerpunten' van de nieuwe wet het volgende op.

\section{Ad a. De mondelinge behandeling}

In de vernieuwde procedure in eerste aanleg zal het pleidooi als zodanig worden afgeschaft. Er komt een mondelinge behandeling waarin de huidige comparitie na antwoord en het pleidooi zullen opgaan. Deze mondelinge behandeling zal de 'spil' van de nieuwe procedure vormen. De regiefunctie van de rechter wordt in dit verband aanzienlijk versterkt. ${ }^{5}$ Dit roept de vraag op wat dat in de praktijk zal betekenen. Hoe zal de rechter omgaan met deze nieuwe regiefunctie en daar concreet invulling aan geven? En wat zal qua voorbereiding op de (nieuwe) mondelinge behandeling van de advocaten (en partijen) worden verwacht? De nieuwe wet biedt de mogelijkheid om (al) bij de mondelinge behandeling getuigen (en partijdeskundigen) te horen. ${ }^{6}$ Wat zal dit voor gevolgen hebben?

\section{Ad b. Het leveren van 'maatwerk'}

De nieuwe wet gaat uit van een (eenvoudige) basisprocedure, die echter in een concreet geval zo nodig tot een 'maatwerkprocedure' kan worden uitgebouwd. In de memorie van toe-

3. Qua literatuur kan o.m. worden gewezen op: J. Ekelmans, Het wetsvoorstel voor de civiele rechtsgang in eerste aanleg: met het hoofd en hard?, NTBR 2014, afl. 8, p. 28-63, H.W. Wefers Bettink, Digitalisering van de civiele procedure: gevolgen voor de procespraktijk, TCR 2015, afl. 1, p. 1-6, K. Teuben \& K.J.O. Jansen, Het Wetsvoorstel vereenvoudiging en digitalisering procesrecht: kanttekeningen vanuit de procespraktijk, TCR 2015, afl. 2, p. 3-12, A.I.M. van Mierlo \& P.J.J. Vonk, Vereenvoudiging en digitalisering van het procesrecht; procederen in nieuwe jas na KEI, WPNR (2015) 7065, p. 511-520 en H. Hofhuis, Vernieuwing van het civiele proces, Trema 2015, afl. 1, p. 10-18.

4. Blijkens de wetsgeschiedenis zijn de regiefunctie van de rechter (in het kader van de vernieuwde mondelinge behandeling) en het leveren van maatwerk belangrijke aspecten van de vernieuwde procedure in eerste aanleg. Zie Kamerstukken II 2014/15, 34059, 3, p. 7 (MvT).

5. Zie art. $30 \mathrm{j} \mathrm{t} / \mathrm{m} \mathrm{30n} \mathrm{van} \mathrm{de} \mathrm{nieuwe} \mathrm{wet.} \mathrm{Zie} \mathrm{ook} \mathrm{Kamerstukken} \mathrm{II}$ 2014/15, 34059, 3, p. 23-24.

6. Zie art. $30 \mathrm{k}$ lid 2 van de nieuwe wet. 
lichting (hierna: MvT) is in dit verband opgemerkt dat de rechter - vanuit zijn verantwoordelijkheid voor een kwalitatief goede uitspraak en een goed verloop van de procedure - in overleg met partijen kan afwijken van de basisprocedure indien en voor zover de aard en/of de complexiteit van het geschil daartoe aanleiding geven. ${ }^{7}$ Besproken wordt op welke wijze dat 'maatwerk' zal kunnen worden geleverd.

De NVvP beoogt met deze vergadering een bijdrage te leveren aan de 'vertaalslag' die van de nieuwe wet naar de praktijk moet worden gemaakt. Hoe zal in de praktijk - door de rechter en partijen - met het vernieuwde procesrecht worden omgegaan? De civiele procedure staat bij deze vergadering (uiteraard) centraal, maar ook zal inspiratie worden ontleend aan de ervaringen die de bestuursrechtspraak inmiddels heeft opgedaan met de zogenoemde 'Nieuwe Zaaksbehandeling'.

Mr. Van Tongeren laat - als advocaat - zijn licht schijnen over het vernieuwde procesrecht, mr. Van de Sande zal - als bestuursrechter - op de ervaringen met de Nieuwe Zaaksbehandeling in de bestuursrechtspraak ingaan en mr. Steenberghe zal - als civiele rechter - met name de nieuwe mondelinge behandeling bespreken.

Stellingen:

\section{Inleiding mr. B.J.R. van Tongeren ${ }^{8}$}

1. KEI levert voor de civiele advocatuur alleen dan meer op als de rechtspraak daardoor efficiënter en sneller wordt.

2. De regierol van de rechter in KEI komt op gespannen voet te staan met de van oudsher lijdelijke rol van een rechter.

\section{Inleiding}

Van Tongeren wijst erop dat bij de behandeling van de begroting van het ministerie van Veiligheid en Justitie - die onlangs in de Tweede Kamer plaatsvond - duidelijk is geworden dat de nieuwe wet in elk geval niet vóór de zomer van 2016 in werking zal treden. De nieuwe wet zal niet alleen het werk van de rechter, maar ook dat van de advocaat raken. Van Tongeren zal vanuit het perspectief van de advocaat op het vernieuwde procesrecht ingaan.

De nieuwe wet behelst (blijkens de MvT) de volgende vijf wezenlijke veranderingen:

1. Een uniforme procesinleiding.

2. In de dagvaardingsprocedure (die in de nieuwe wet 'vorderingsprocedure' wordt genoemd) is het niet langer noodzakelijk om de deurwaarder in te schakelen. Alleen als de gedaagde niet in het geding verschijnt, zal de eiser voor het (kunnen) verkrijgen van een verstekvonnis de procesinlei-

7. Kamerstukken II 2014/15, 34059, 3, p. 1 (MvT).

8. Advocaat te Rotterdam, portefeuillehouder KEI in de Algemene Raad van de NOvA en waarnemend deken. Volledigheidshalve wordt hier ook gewezen op het interview met Van Tongeren (als lid van de Algemene Raad van de NOvA met IT in zijn portefeuille) en Frits Bakker (de voorzitter van de Raad voor de rechtspraak) in Advocatenblad 2014, afl. 10, p. 22-26 (getiteld 'We kunnen niet op papier blijven werken'). ding alsnog door een deurwaarder aan de gedaagde moeten laten betekenen. ${ }^{9}$

3. Er komen voor zowel de rechter als partijen meer (en nieuwe) wettelijke termijnen. ${ }^{10}$

4. De rechter krijgt een sterkere regierol, waardoor hij meer sturing aan het verloop van de procedure kan geven. Zo kan de rechter de mondelinge behandeling afstemmen op de bijzonderheden van de zaak en afwijken van het stramien van de basisprocedure indien de aard of de complexiteit van de zaak dat vergt. ${ }^{11}$

5. Partijen worden in beginsel verplicht om langs elektronische weg te procederen en hun processtukken digitaal in te dienen. ${ }^{12}$

Gelet op de hem toegemeten spreektijd werkt Van Tongeren alleen de vierde wijziging nader uit. De regierol die de rechter in de nieuwe wet krijgt, zal een ingrijpende wijziging van de (traditionele) verhouding tussen de rechter en partijen tot gevolg hebben.

Van Tongeren merkt op dat de missie van KEI niet nieuw is en in een rijke traditie staat. Sinds de negentiende eeuw zijn herhaaldelijk pogingen ondernomen om het burgerlijk proces tot een eenvoudiger en meer efficiënte rechtsgang te hervormen. In enkele gevallen hebben deze pogingen tot concrete resultaten geleid. Zo is het initiatief van de Amsterdamse advocaat Abraham Hartogh uitgemond in de 'Lex Hartogh'. De doelstelling van deze in 1897 in werking getreden wet was 'een vereenvoudiging en bespoediging der procedure'. Een ander lid van de balie, de Amsterdamse advocaat Johan Caroli, heeft in belangrijke mate bijgedragen aan de toegenomen populariteit (in het begin van de twintigste eeuw) van het kort geding. Door diens baanbrekende werk ontwikkelde zich in de rechtspraak de opvatting dat de rechter in de bodemzaak niet gebonden is aan het (voorlopige) oordeel dat eerder in een kort geding over het geschil is geveld. ${ }^{13}$

Sommige hervormingspogingen waren evenwel minder succesvol. Zo heeft het werk van de commissie-Gratama geen resultaat opgeleverd. Deze in 1911 ingestelde staatscommissie moest adviseren over een herziening van het Wetboek van Burgerlijke Rechtsvordering ( $\mathrm{Rv})$. De commissie heeft een ontwerp van wet gemaakt waarmee uiteindelijk niks is gedaan. Dat is jammer, want het bevatte moderne voorstellen. De commissie heeft zich onder meer gebogen over de vraag of materiële waarheidsvinding als een algemeen beginsel van het civiele procesrecht moet worden beschouwd. Hoewel sommige commissieleden beducht waren voor het risico dat de rechter zou gaan 'meeprocederen' (hetgeen afbreuk aan zijn onpartijdigheid zou doen), achtte de commissie het gewenst dat de

9. Zie art. 112 en het gewijzigde art. 139 van de nieuwe wet.

10. Zie o.m. art. 30q van de nieuwe wet.

11. Zie o.m. art. $30 \mathrm{k}$ van de nieuwe wet.

12. Zie Kamerstukken II 2014/15, 34059, 3, p. 5 en 15-42 (MvT).

13. De regel dat de bodemrechter niet is gebonden aan het oordeel van de voorzieningenrechter in een kort geding is thans in art. $257 \mathrm{Rv}$ terug te vinden. 
civiele rechter - binnen de door partijen bepaalde grenzen van de rechtsstrijd - meer dan tot dan toe gebruikelijk was tot de materiële waarheid zou moeten kunnen doordringen.

Maar het advies van de commissie-Gratama heeft - zoals gezegd - niet tot een wetswijziging geleid. Voor zover het de waarheidsvinding betreft, geldt thans nog steeds de taakverdeling tussen rechter en partijen zoals vervat in art. 24 en 149 $\mathrm{Rv}$, inhoudend dat het de rechter verboden is om de (door partijen gestelde) feiten aan te vullen of de feitelijke grondslag uit te breiden. De rechter is derhalve gebonden aan hetgeen door partijen is aangevoerd (met dien verstande dat hij ingevolge art. $25 \mathrm{Rv}$ wel de rechtsgronden mag aanvullen).

Van Tongeren wijst erop dat de rechter ten aanzien van de feitengaring wel meer bevoegdheden heeft gekregen bij de herziening van het burgerlijk procesrecht in 2002. Sinds $2002 \mathrm{kan}$ hij partijen bevelen om bepaalde stellingen toe te lichten en/of op de zaak betrekking hebbende stukken over te leggen (art. $22 \mathrm{Rv}$ ). Tevens is in de wet vastgelegd dat op de procederende partijen een waarheidsplicht rust (art. $21 \mathrm{Rv})$. De rechter wordt hiermee in staat gesteld om de feiten boven tafel te krijgen, teneinde te voorkomen dat hij op basis van onjuiste en/of onvolledige feiten een oordeel velt.

De Commissie Fundamentele Herbezinning ging in haar Interimrapport uit $2003^{14}$ en haar Eindrapport uit $2006^{15}$ nog verder door ervoor te pleiten om de partijautonomie (nog) verder in te perken. De commissie legde de nadruk op de gezamenlijke verantwoordelijkheid van rechter en partijen voor het verloop van de procedure. Die verantwoordelijkheid nodigt uit tot een actieve opstelling van zowel rechter als partijen, maar beperkt ook de keuzevrijheid ('autonomie') van partijen.

De advocatuur zelf was zich eveneens bewust van de verantwoordelijkheid die (ook) de advocaat draagt voor een prudent gebruik van de rechtspleging en de rechtsgang. Van Tongeren refereert in dit verband aan het onderzoek van de Commissie Advocatuur naar de positie van de advocaat binnen de maatschappelijke orde. De commissie heeft een zesde kernwaarde voor de advocaat geformuleerd (naast de al bestaande 'echte' kernwaarden): het belang van een goede rechtsbedeling.

De nieuwe wet brengt geen verandering in het uitgangspunt dat partijen de omvang van het geding bepalen (zoals ook in art. $23 \mathrm{Rv}$ is vastgelegd). Wel krijgt de rechter meer mogelijkheden om de regie te voeren ten aanzien van het verloop van de procedure. Dit zal volgens de MvT kunnen bijdragen aan kortere doorlooptijden en meer tevredenheid onder justitiabelen doordat procedures beter aansluiten op de behoeften in een specifieke zaak: de rechter bepaalt welke proceshandelingen

14. W.D.H. Asser, H.A. Groen \& J.B.M. Vranken, Een nieuwe balans. Interimrapport Fundamentele herbezinning Nederlands burgerlijk procesrecht, Den Haag: Boom Juridische uitgevers 2003.

15. W.D.H. Asser, H.A. Groen \& J.B.M. Vranken, Uitgebalanceerd. Eindrapport Fundamentele herbezinning Nederlands burgerlijk procesrecht, Den Haag: Boom Juridische uitgevers 2006. door partijen kunnen worden verricht (en tot welk moment). Het ligt wel voor de hand dat de rechter overleg met partijen voert over belangrijke procedurele beslissingen. De rechter dient in dit verband de belangen van partijen af te wegen tegen het belang van een snelle en doelmatige procesvoering, zo is in de MvT benadrukt. ${ }^{16}$

De regierol van de rechter krijgt met name vorm in het nieuwe art. 19 lid $2 \mathrm{Rv}$, waarin is bepaald:

'De rechter neemt ambtshalve of op verlangen van een van de partijen alle beslissingen die nodig zijn voor een goed verloop van de procedure.'

Van Tongeren merkt op dat uitdrukkelijk niet voor een instemmingsrecht is gekozen (gezien de geringe kans dat partijen het met elkaar eens zullen worden). Tegen een door de rechter op grond van het nieuwe art. 19 lid $2 \mathrm{Rv}$ genomen beslissing zal ingevolge art. 337 lid $2 \mathrm{Rv}$ slechts tegelijk met appel tegen het eindvonnis hoger beroep kunnen worden ingesteld.

'Wie heeft feitelijk de touwtjes in handen?', zo vraagt Van Tongeren zich af. Daarmee doelt hij op de praktische aspecten van de procedure, waaronder de uitwisseling van processtukken. Het uitgangspunt van KEI is dat de eisende partij de verantwoordelijkheid voor de oproeping van de wederpartij draagt. In de nieuwe basisprocedure zullen partijen processtukken uitsluitend bij het gerecht indienen en wordt dus niet langer (ook) een exemplaar aan de wederpartij gezonden (een ingediend processtuk wordt vervolgens via het digitale systeem van gegevensverwerking door het gerecht aan alle betrokkenen doorgestuurd). Is dit wel geoorloofd in het licht van de voor advocaten geldende gedragsregel 15 ? Die regel houdt in dat de advocaat die een schriftelijk stuk aan de rechter zendt, gelijktijdig een afschrift daarvan aan de advocaat van de wederpartij behoort te sturen. Het is aan de tuchtrechter om de vraag of de nieuwe wijze van procederen zich verdraagt met gedragsregel 15 te beantwoorden, aldus Van Tongeren. Aannemend echter dat de ratio van die regel handhaving van 'equality of arms' is, komt het hem voor dat dit doel ook met de nieuwe werkwijze zal (kunnen) worden bereikt.

Van Tongeren sluit zijn voordracht af met de opmerking dat de invoering van de nieuwe wet ongetwijfeld ook voor de advocatuur tot nieuwe inzichten zal leiden.

\section{Discussie}

Mevrouw Tzankova (hoogleraar aan de Universiteit van Tilburg en advocaat) merkt op dat vooral de dialoog tussen rechter en partijen van belang is. Het is niet de bedoeling dat spra$k e$ is van 'eenrichtingsverkeer' van de rechter naar partijen. Zo nodig moet de rechter knopen doorhakken, maar de dialoog tussen rechter en partijen is cruciaal.

16. Kamerstukken II 2014/15, 34059, 3, p. 27-28 (MvT). 
De heer Steenberghe (rechter) voegt daaraan toe dat de rechter 'de touwtjes in handen heeft'. Echter: partijen bepalen wat die 'touwtjes' zijn.

In zijn reactie op deze opmerkingen geeft Van Tongeren aan dat nu niet altijd even duidelijk is hoe actief de rechter zal zijn. Naar zijn mening is vooral van belang dat partijen (en hun advocaten) vooraf weten wat zij van de mondelinge behandeling - en de rechter - kunnen verwachten. Volgens hem kan het nieuwe art. 19 lid 2 Rv daarvoor een goede 'kapstok' bieden.

De heer Van Schaick (hoogleraar aan de Universiteit van Tilburg, advocaat en raadsheer-plaatsvervanger) stelt dat van een 'tegenstelling' tussen rechter en partijen - zijns inziens - geen sprake is. Het belang van de mondelinge behandeling is volgens hem wel toegenomen, mede door de 'open normen' in het civiele recht. Die 'open normen' vergen namelijk een meer actieve opstelling van de rechter.

Van Tongeren ziet dat toch anders. Naar zijn mening heeft de advocaat dogmatisch gezien een (fundamenteel) andere rol dan de rechter. De advocaat dient allereerst het belang van zijn eigen cliënt (en dat geldt niet voor de rechter). De principiële tegenstelling tussen de rechter en partijen (en hun raadslieden) blijft derhalve onverminderd actueel.

\section{Stellingen:}

\section{Inleiding mw. mr. J.M.W. van de Sande ${ }^{17}$}

1. De regievoering in de Nieuwe Zaaksbehandeling is gericht op oplossingen en al te veel verwachtingenmanagement kan in de weg staan aan de beste oplossing.

2. Het belangrijkste KEI-project is het deelprogramma Cultuur, Gedrag en Leiderschap.

3. Het is nog maar de vraag of de advocatuur een van de belangrijkste sparringpartners van de rechtspraak blijft.

\section{Inleiding}

Van de Sande gaat in haar voordracht in op de vraag in hoeverre de tegenwoordig in bestuursrechtelijke zaken gehanteerde Nieuwe Zaaksbehandeling (hierna: NZB) kan bijdragen aan een bevordering van de kwaliteit van de rechtspraak. De NZB, een in 2012 geïntroduceerde nieuwe werkwijze voor de bestuursrechter, staat in de kern voor een zaaksbehandeling waarbij het geschil tussen de betrokken partijen (ter zitting) niet alleen vanuit een juridische invalshoek, maar ook vanuit andere invalshoeken wordt bekeken. De rechter beperkt zich dus niet tot een strikt juridische benadering van de zaak, maar toont zich ook geïnteresseerd in het achterliggende conflict tussen partijen. Hij dient actief voor procedurele rechtvaardigheid te zorgen en bespreekt met partijen - met oog voor de tussen hen spelende belangen - wat de meest adequate behan-

17. Senior rechter inhoudelijk bij de sector bestuursrecht van de Rechtbank Gelderland. deling van de zaak kan zijn. ${ }^{18}$ Van de Sande is tevens lid van de landelijke expertgroep NZB, maar zij benadrukt dat zij haar voordracht op persoonlijke titel houdt.

Om een indruk van de NZB te geven refereert Van de Sande aan een zaak die zij onlangs zelf als bestuursrechter heeft behandeld. Een burger (hierna: eiser) had beroep bij de rechtbank ingesteld tegen een door de gemeente aan hem opgelegde aanslag afvalstoffenheffing. Dat was al vaker gebeurd: eiser had ook beroep ingesteld tegen de aanslagen die in de jaren daarvoor aan hem waren opgelegd. Een aanslag afvalstoffenheffing mag er slechts toe strekken dat de (werkelijke) kosten die de gemeente aangaande afvalstoffen heeft, worden gedekt. De gemeente mag er dus geen 'winst' op maken. Eiser koesterde wantrouwen, kennelijk had hij het idee dat de gemeente wél meer dan de werkelijke kosten in rekening bracht. Bij een benadering 'oude stijl' zou de zaak als een strikt 'juridische puzzel' zijn aangepakt, uitmondend in een uitspraak. Maar zou dat een goede 'oplossing' zijn geweest? Waarschijnlijk niet, want het wantrouwen van eiser zou door een uitspraak niet zijn verdwenen en vermoedelijk zou hij tegen de volgende aanslag opnieuw beroep hebben ingesteld.

De NZB kenmerkt zich erdoor dat de rechter ter zitting onderzoekt wat partijen daadwerkelijk verder kan helpen. Dat is wat Van de Sande en haar collega-rechters in de geschetste zaak ook hebben gedaan: door ter zitting bij partijen te informeren naar de achtergronden van hun conflict is naar een bevredigende oplossing gezocht. Naar aanleiding van de door de rechters ter zitting gestelde vragen bleek onder meer dat eiser zelf in het verleden bij een andere gemeente werkzaam was geweest en zich daar bezig had gehouden met de gemeentelijke begroting aangaande de afvalstoffenheffing. Door niet uitsluitend de juridische merites te bespreken maar ook andere vragen te stellen, kwam er meer zicht op de (psychologische) achtergronden van het conflict en werden partijen er meer ontvankelijk voor om door middel van (iets als) een dialoog tot een oplossing te komen. Uiteindelijk hebben partijen er (ter zitting) mee ingestemd dat een poging zou worden ondernomen om hun conflict via mediation uit de wereld te helpen. Van de Sande benadrukt dat dit - zeer waarschijnlijk - niet zou zijn gelukt als de zaak op de 'oude manier' zou zijn behandeld. Het gaat dus in de kern om de invalshoek vanwaaruit het geschil wordt benaderd (door de rechter): als een puur juridisch geschil of als een conflict tussen overheid en burger. Volgens Van de Sande is dat de NZB 'in a nutshell'. Daar waar de rechter voorheen als een 'ondoorgrondelijke sfinx' optrad, is hij bij de NZB een 'herder van het proces'.

Van de Sande wijst erop dat bij de NZB, evenals in de nieuwe wet, de zitting centraal staat. De zitting kan volgens haar de volgende (concrete) 'opbrengsten' opleveren:

18. Zie Kamerstukken II 2014/15, 34059, 3, p. 28 (MvT). Zie ook B. Marseille, B. de Waard \& P. Laskewitz, De Nieuwe zaaksbehandeling in het bestuursrecht in de praktijk, NJB 2015, afl. 29, p. 2006-2014. 
- Het beproeven van een schikking of het aftasten van de mogelijkheden om het geschil door middel van mediation op te lossen.

- Het ter zitting bieden van duidelijkheid (door de rechter) over de juridische merites van de zaak kan leiden tot een beter begrip aangaande de bewijspositie en het eventueel spontaan aanbieden van bewijs. Bovendien kan inzicht worden gegeven (aan partijen) in de aspecten die zich wel en de aspecten die zich niet voor een juridische oplossing lenen. Dit zal leiden tot kwalitatief betere beslissingen en uitspraken.

Van de Sande gaat vervolgens in op de pijlers van de NZB, ook ter vergelijking met de uitgangspunten van KEI. De eerste pijler van de NZB is een snelle, finale geschilbeslechting en het verzekeren van materiële aanspraken. Een informele aanpak, gericht op het vinden van een oplossing, staat daarbij centraal. In zoverre is de NZB ook een reactie op doorgeschoten formalisme. Een tweede pijler wordt gevormd door nieuwe, aan de sociale psychologie ontleende inzichten. Van de Sande refereert in dit verband aan het onderzoek dat Van den Bos naar procedurele rechtvaardigheid heeft gedaan. Hij sprak hierover bij de voorjaarsvergadering van de NVvP van $2014 .{ }^{19}$ Tevens wijst zij op het werk van de Nationale ombudsman, waardoor meer duidelijkheid is ontstaan over de redenen waarom burger en overheid met elkaar in conflict raken. In feite gaat het om een botsing van twee leefwerelden, namelijk die van niet-juridische mensen 'van vlees en bloed' met technische bureaucraten. Daarnaast kan volgens Van de Sande nog een derde pijler worden onderscheiden, namelijk die van de nieuwe ideeën in de samenleving over 'vraaggestuurd werken'. Hierbij moet worden gedacht aan buurtzorg, beleidsbemiddeling en dergelijke. De rechtzoekende staat bij de NZB centraal.

Wat mag anno 2015 van de NZB worden verwacht? Van de Sande wijst op de uitkomsten van twee recente onderzoeken. Allereerst het onderzoek van Marseille, De Waard en Laskewitz (hierna: Marseille c.s.). Marseille c.s. hebben onderzocht in hoeverre de nieuwe werkwijze van de NZB heeft opgeleverd wat er vooraf van werd verwacht. $Z_{i j}$ hebben in dit verband bij vijf verschillende rechtbanken - 150 zittingen geobserveerd en ruim 300 interviews afgenomen met zowel rechters als procespartijen. Tevens zijn de uitspraken in zaken waarvan de zitting was bijgewoond, geanalyseerd. In een bijdrage in het Nederlands Juristenblad van september 2015 hebben Marseille c.s. verslag van (de uitkomsten van) hun onderzoek gedaan. ${ }^{20}$ Van de Sande memoreert enkele van de door Marseille c.s. getrokken conclusies. Er bleken grote verschillen te zijn in de werkwijze op de zitting, zowel tussen de in het onderzoek betrokken rechtbanken alsook tussen de rechters per rechtbank. Slechts bij één rechtbank (Van de Sande veronderstelt de Rechtbank Midden-Nederland) verliepen de zittin-

19. Zie hierover J.J. Dammingh \& P.E. Ernste, Procedurele en distributieve rechtvaardigheid, Verslag van de voorjaarsvergadering 2014 van de Nederlandse Vereniging voor Procesrecht, TCR 2014, afl. 4, p. 128-129.

20. Marseille, De Waard \& Laskewitz 2015. gen regelmatig volgens het stramien van de NZB. Een tweede conclusie van Marseille c.s. is dat er een significant verschil blijkt te zijn tussen de procespartijen voor wat betreft de karakterisering van hun geschil: de gemachtigden van het betrokken bestuursorgaan (de verweerster) menen vaak dat sprake is van een eenduidig juridisch geschil, terwijl het volgens de gemachtigden van de eiser vaak om een conflict met uiteenlopende aspecten (dus niet alleen maar juridische) gaat. Hieruit valt af te leiden dat het perspectief van de rechtzoekende voor een belangrijk deel niet-juridisch is. Dan kan de oplossing vanzelfsprekend niet alleen maar strikt juridisch zijn, aldus Van de Sande. Een derde belangrijke conclusie vindt Van de Sande dat de attitude van de rechter vaak van doorslaggevend belang is voor het slagen van de NZB. Significant is volgens haar ook dat het onderzoek van Marseille c.s. heeft uitgewezen dat tegen uitspraken van rechters die blijkens de afgenomen interviews enthousiast over de NZB zijn, aanmerkelijk minder is geappelleerd.

Van de Sande wijst ten tweede op het onderzoek van Broekema, die in 2015 aan de Rijksuniversiteit Groningen promoveerde op een onderzoek onder de titel 'De stap naar hoger beroep. Een onderzoek naar appelgedrag van burgers in bestuursrechtelijke zaken'. ${ }^{21}$ De bevindingen van Broekema sluiten in belangrijke mate aan bij de uitkomsten van het onderzoek van Marseille c.s. Naarmate partijen de wijze van behandeling als meer procedureel rechtvaardig hebben ervaren, zullen zij minder geneigd zijn tot het instellen van hoger beroep. Ook heeft Broekema geconcludeerd dat tegen een begrijpelijke, goed gemotiveerde uitspraak in het algemeen minder snel hoger beroep wordt ingesteld.

In ieder geval wijzen de onderzoeken van Marseille c.s. en Broekema - volgens Van de Sande - uit dat méér eenduidigheid is vereist, dat de attitude van de rechter jegens de NZB van cruciale betekenis is voor het (kunnen) slagen van de NZB en dat er meer aandacht behoort te zijn voor de (door partijen ervaren) procedurele rechtvaardigheid.

Ter afsluiting van haar voordracht refereert Van de Sande nog aan de aanbevelingen voor (een verbetering van) de toegang tot het recht die recentelijk door een aantal gezaghebbende juristen zijn gedaan. $\mathrm{Zij}$ noemt drie van die aanbevelingen:

- Financieringssystemen zouden een 'incentive' moeten behelzen voor oplossingen (thans is het voeren van procedures op zich 'winstgevend').

- Er zouden meer mogelijkheden moeten zijn om innovaties te stimuleren die de gevestigde monopolies van rechtspraak, advocatuur en deurwaarders kunnen doorbreken.

- Wetgeving zou 'IKEA-proof moeten zijn, waarmee wordt bedoeld dat de wet goed te begrijpen en toe te passen moet zijn zonder de bijstand van dure deskundigen.

21. I.M. Broekema, De stap naar hoger beroep. Een onderzoek naar appelgedrag van burgers in bestuursrechtelijke zaken (diss. Groningen), Den Haag: Boom Juridische uitgevers 2015. 


\section{Discussie}

De heer Den Tonkelaar (rechter en hoogleraar aan de Radboud Universiteit te Nijmegen) merkt op dat Van Tongeren en Van de Sande allebei in hun voordracht de aandacht hebben gevestigd op procedurele rechtvaardigheid. Hij wijst erop dat tevens de bedoeling van KEI is dat de zaaksrechter zich al in een vroegtijdig stadium over het verloop van de procedure buigt, en in dat kader ook overleg met partijen zal (moeten) plegen.

De heer Rueb (advocaat) wijst op het traditionele onderscheid tussen het burgerlijk proces en het proces in het bestuursrecht: in het civiele proces wordt eerst een processueel debat gevoerd, waarna (eventueel) een bewijsopdracht wordt gegeven. Dat is in het bestuursrecht anders. De reactie van Van de Sande komt erop neer dat de procedure in het bestuursrecht een onduidelijk bewijsrecht kent.

Mevrouw Ahsmann (rechter en hoogleraar aan de Universiteit Leiden) onderschrijft de traditie in het civiele proces dat de rechter pas halverwege het proces een bewijsopdracht verstrekt. De mondelinge behandeling staat in de nieuwe wet centraal, maar volgens haar geeft de wetgever te weinig 'handvatten' aan de rechter ten aanzien van de (concrete) invulling van de mondelinge behandeling. Dit betekent voor de praktijk dat veel zal afhangen van de rechter die de zaak behandelt (en de mondelinge behandeling voorzit).

Stellingen:

\section{Inleiding mr. H.M.M. Steenberghe ${ }^{22}$}

1. Het gebruik van de nieuwe procesrechtelijke instrumenten van KEI zal de kwaliteit van de rechtspraak bevorderen.

2. Het uitspreken van een mondeling vonnis tast het gezag van de civiele rechter aan.

3. Het voorstel om de door de rechter te voeren regie op een aparte zitting te bespreken is niet realistisch.

4. Naarmate de keuzevrijheid van de rechter in de te voeren regie en in de daarvoor te hanteren instrumenten toeneemt, wordt afstemming van de verwachtingen van partijen van meer belang.

5. Naarmate de keuzevrijheid van de rechter in de te voeren regie en in de daarvoor te hanteren instrumenten toeneemt, worden landelijke op rechtseenheid gerichte afspraken van meer belang.

\section{Inleiding}

Steenberghe behandelt in zijn voordracht enkele inhoudelijke aspecten van KEI die het hart van de procedure betreffen: de mondelinge behandeling. Aan de hand van vijf thema's, te weten procedurele rechtvaardigheid, waarheidsvinding, conflictoplossing en finaliteit, aandacht voor de persoon van de rechter en sturen op efficiency en snelheid, laat hij zes 'KEIinstrumenten' de revue passeren: de regiefunctie van de rechter, de directe communicatie tussen advocaten en rechter, de

22. Senior rechter bij de sector civiel recht van de Rechtbank MiddenNederland en lid van de Adviescommissie Burgerlijk Procesrecht. agenda, het gebruik van pleitaantekeningen, het horen van getuigen en deskundigen bij de mondelinge behandeling en het mondelinge vonnis.

\section{De regiefunctie van de rechter}

De inhoud van de regiefunctie van de civiele rechter is een onderwerp voor een fundamentele discussie. Regie en takuitoefening zijn twee zijden van dezelfde medaille. Maar de medaille die iedere rechter draagt, is geen serieproduct. Steenberghe vermoedt dat alle civiele rechters zullen beamen dat zij een taak hebben als feitenvaststeller, rechtstoepasser, probleemoplosser en procesbewaker en, meer overkoepelend, de taak om ervoor te zorgen dat de procesdeelnemers de procedure als rechtvaardig ervaren. Over de uitvoering wordt echter verschillend gedacht. Afhankelijk van persoonlijke visie, overtuiging, ervaring en talent bestaan verschillen tussen rechters ten aanzien van het bespreken van de feiten, het beproeven van een schikking en/of het achterhalen van achterliggende belangen. Er is nog lang niet zoiets als een eenduidige visie op de taakvervulling door de civiele rechter. Wanneer gaat het nemen van autonome verantwoordelijkheid voor de kwaliteit van het oordeel over in meeprocederen? En hoe verhoudt zich het rechtspreken tot bemiddelen? Over deze vragen wordt door rechters verschillend gedacht. Maar uiteindelijk wel vanuit de vrijheid en verantwoordelijkheid die iedere rechter voelt om in elke zaak te voorzien in goede rechtspraak. Wanneer, zoals met KEI, de mogelijkheden voor maatwerk toenemen, wordt belangrijker dat voor de procesdeelnemers duidelijk is wat zij in hun zaak van elkaar mogen verwachten. In de civiele rechtspleging wordt duidelijkheid in de voorfase op landelijk niveau verschaft met de procesreglementen en het hanteren daarvan door de rolrechters. Op zaaksniveau vindt in de voorfase niet standaard afstemming plaats. Afstemming is afhankelijk van het beleid van het gerecht, de inhoud van het comparitievonnis en het initiatief van de rechter en soms een advocaat, en vindt doorgaans plaats ter zitting, als het al gebeurt. Willen regie, de takkuitoefening van de rechter en maatwerk samengaan met procedurele rechtvaardigheid, effectieve zaaksbehandeling en efficiënte gedingvoering, dan is vereist dat in de voorfase van de procedure afstemming plaatsvindt van wat de procesdeelnemers van de mondelinge behandeling mogen verwachten, aldus Steenberghe. De overige 'KEI-instrumenten' komen dan in beeld.

\section{De agenda}

De advocatuur beklaagt zich er volgens Steenberghe terecht over dat tevoren niet duidelijk is wat tijdens de mondelinge behandeling besproken zal worden. Zeker omdat ook niet gepleit mag worden. Het in de voorfase verschaffen van duidelijkheid over de te bespreken onderwerpen is uit het oogpunt van procedurele rechtvaardigheid en efficiency wenselijk. Het stimuleert een betere voorbereiding, tempert wellicht de behoefte om te pleiten en geeft partijen mogelijk al enig inzicht in de gedachtegang van de rechter. In art. 30k lid 3 van de nieuwe wet staat dat de griffier partijen zo mogelijk vooraf informeert over het doel van de mondelinge behandeling. 
Steenberghe acht de vaststelling van de agenda uit het oogpunt van het duidelijk maken van wederzijdse verwachtingen van groot belang. De agenda moet geen eenzijdig bericht van de griffier zijn, zoals in art. 30k lid 3 is vermeld, maar onderwerp van onderlinge afstemming. Hiervoor moet een voorziening in het procesreglement worden opgenomen. Juist op dit punt kan directe digitale communicatie tussen rechter en advocaten worden ingezet.

\section{Het pleiten ter zitting}

In art. $30 \mathrm{k}$ lid 1 van de nieuwe wet staat dat de rechter partijen in de gelegenheid stelt hun stellingen toe te lichten. De huidige comparitiepraktijk is verdeeld. Dit wordt alom, ook door de rechtspraak, als onwenselijk gezien. Achter dit verschil gaat een verschil in taakopvatting schuil: de actieve zittingsrechter moet niets van pleiten hebben, de meer lijdelijke rechter verwelkomt het juist. De rechter die zijn bemiddelende functie hoog in het vaandel voert, heeft doorgaans moeite met pleitende advocaten omdat zij de zittingsdynamiek platslaan en de standpunten zich verharden. Deze achtergrond maakt dat dit onderwerp bij rechters gevoelig ligt. Ook vanuit efficiencyoogpunt zijn er aarzelingen omdat pleiten vaak een herhaling is van wat al in de stukken staat. Steenberghe is van mening dat een pleitverbod in strijd is met art. $30 \mathrm{k}$ lid 1 van de nieuwe wet en art. 6 van het Europees Verdrag tot bescherming van de rechten van de mens en de fundamentele vrijheden (EVRM). De mondelinge behandeling moet echter geen pleidooi worden in de klassieke betekenis. In het procesreglement moet worden opgenomen dat aan partijen desgewenst de gelegenheid wordt geboden hun standpunt aan de hand van op schrift gestelde aantekeningen toe te lichten en dat daar maximaal tien minuten voor wordt gereserveerd met, op verzoek, een verlenging van maximaal nog eens tien minuten. In de voorfase dient aan partijen te worden verzocht aan te geven of zij van deze gelegenheid gebruik zullen maken. Voordeel van een dergelijke opgave is dat beide partijen van elkaar weten wat men van plan is. Advocaten is op deze wijze duidelijk waarop zij aanspraak kunnen maken. En op zaaksniveau is duidelijk wat de procesdeelnemers gaan doen. Op deze wijze worden procedurele rechtvaardigheid, efficiency en het belang van een kwalitatief goed procesverloop gediend.

\section{Het horen van getuigen en deskundigen tijdens de mondelinge behandeling}

Tijdens de mondelinge behandeling kunnen getuigen en partijdeskundigen worden gehoord, mits daarvoor voorafgaand toestemming is verleend (art. $30 \mathrm{k}$ lid 2 van de nieuwe wet). De afstemming in de voorfase heeft hier een wettelijke basis. In de literatuur wordt deze mogelijkheid gecompliceerd geacht. Van een duidelijke bewijsopdracht is dan immers nog geen sprake en er ontstaat recht op een contra-enquête. Efficiënt is het dus niet, is de gedachte. Toch verwacht Steenberghe er wel iets van. Waarheidsvinding ter zitting is thans doorgaans een gesprek met een zeker informeel karakter. Om de feiten te verzamelen spreekt de rechter rechtstreeks met partijen en met de door hen meegenomen betrokkenen. Dat moet worden toege- juicht, want al feiten verzamelend groeit een overtuiging en die heb je als rechter nodig. Maar feitenonderzoek en bewijsgaring lopen ter zitting zo wel door elkaar. Steenberghe vraagt zich af of het informele gesprek wel de juiste methode is voor deugdelijk feitenonderzoek. Beter is het indien de feitengaring, zeker waar het cruciale feiten betreft die niet vaststaan, onder ede geschiedt. Dit komt de waarheidsvinding ten goede, omdat partijen dan in de gelegenheid zijn om vragen aan de getuige te stellen en omdat er aandacht is voor 'equality of arms'; ook de andere partij mag vragen aan de getuige stellen. In een informele setting van een gesprek ter zitting zijn deze waarborgen veel minder vanzelfsprekend. Ook in dit opzicht is afstemming in de voorfase belangrijk. Aan partijen moet worden gevraagd aan te geven welke personen mee naar de zitting komen, wie waarover als getuige gehoord zou kunnen worden en of voor dat horen toestemming wordt gevraagd. Het belang van afstemming van verwachtingen brengt mee dat de rechter bij voorkeur tijdig voor de mondelinge behandeling laat weten wie waarover als getuige gehoord kan worden. Het grote probleem is echter de planning en de voor de zitting beschikbare tijd. Zelfs in een eenvoudige zaak kan een comparitie gecombineerd met het afnemen van een aantal verhoren zomaar zes uur duren. Concentratie van de mondelinge behandeling en getuigenverhoor zal substantieel meer zittingstijd vragen.

\section{Het mondelinge vonnis}

Indien alle partijen op de mondelinge behandeling verschijnen, kan ter zitting mondeling vonnis worden uitgesproken (art. 30p van de nieuwe wet). De mogelijkheid om mondeling een eindvonnis uit te spreken is nieuw. Daar wordt, dezer dagen vooral door rechters met managementtaken, veel van verwacht. Steenberghe vraagt zich af of een mondeling vonnis wel aan de wettelijke kwaliteitseisen kan voldoen, maar tegelijkertijd realiseert hij zich dat het in de huidige praktijk ook niet ongebruikelijk is dat de rechter bij de comparitie na antwoord al een voorlopig oordeel uitspreekt. Positief is dat partijen met een mondeling vonnis snel duidelijkheid hebben. Negatief lijkt de beperkte mogelijkheid tot motiveren, terwijl toch geleerd wordt dat een goed gemotiveerd vonnis bijdraagt aan de acceptatie ervan. Zullen partijen niet vanwege de beperkte motivering eerder in hoger beroep gaan, omdat de rechter geen woord gewijd heeft aan een argument dat die partij nu juist zo van belang achtte? Dit roept vragen op van efficiency en finaliteit. Bovendien kan het gezag van de rechter eronder lijden als de advocaat dagen van voorbereiding in de zaak heeft zitten en de rechter binnen tien minuten afhamert. Jan Vranken heeft prachtig geschreven over het circulaire proces tussen feitenvaststelling en rechtstoepassing. ${ }^{23}$ Motor van dat proces is de beslissingsdwang die de rechter heeft. De mogelijkheid van een mondeling vonnis zet de beslissingsdwang wellicht onder tijdsdruk. Steenberghe vraagt zich af of het risico c.q. de verleiding dat rechters intuïtief in plaats van weloverwogen te werk gaan, niet te groot wordt. Denkbaar is bovendien dat de mogelijk-

23. Asser/Vranken, Algemeen deel** 1995 , hoofdstuk V. De kwadratuur van de cirkel. 
heid van een mondeling vonnis de conflictoplossende taak van de rechter beïnvloedt. Wat te doen als een partij desgevraagd verklaart geen voorlopig oordeel maar een mondeling eindvonnis te willen? Wat is je voorlopig oordeel nog waard als je dan moet erkennen dat je daar nog niet toe in staat bent? Volgens Steenberghe moet met het mondelinge vonnis voorzichtig en verantwoord worden omgegaan. Van groot belang is dat de rechter ter zitting, voordat hij mondeling uitspraak doet, de gelegenheid heeft om afstand te nemen, na te denken en overleg te plegen. Dat vereist de aanwezigheid van een secretaris die inhoudelijk van de zaak op de hoogte is. Deze eis past helemaal in het kwaliteitssysteem dat doorgaans in handelszaken wordt gehanteerd: een vonnis wordt altijd door een collega meegelezen alvorens het uitgesproken wordt. Het moment van overdenking, van overleg en uitleg kost tijd. Goede en ruimhartige planning is dus ook hier van groot belang, evenals het afstemmen van verwachtingen in de voorfase. Het lijkt Steenberghe verstandig partijen in bepaalde zaken, bijvoorbeeld huur- en incassozaken, vooraf te informeren over de mogelijkheid van een mondeling vonnis en partijen te vragen of zij prijs stellen op een mondeling vonnis.

\section{Waar moet het naartoe?}

Steenberghe pleit aldus voor effectief en gelijkwaardig vooroverleg over de agenda van de comparitie, de personen die ter zitting verschijnen en het eventueel ter zitting horen van getuigen of een partijdeskundige, het gebruik van schriftelijke pleitaantekeningen en de mogelijkheid c.q. wenselijkheid van een mondeling vonnis. En wel op een zodanig tijdstip dat bij de vaststelling van de zittingstijd rekening gehouden kan worden met wat procesdeelnemers van de zitting en elkaar verwachten. Daarnaast acht Steenberghe van belang dat in de voorfase ook afstemming kan plaatsvinden over de wens van partijen om de comparitie al of niet te gebruiken voor schikkingsoverleg. De zittingstijd kan dan beter worden ingeschat. Partijen weten van elkaar of zij bereid zijn tot overleg. Zij kunnen zich, evenals de advocaten en de rechter, voorbereiden op het treffen van een regeling. Dergelijke afstemming kan op zichzelf reeds tot een minnelijke regeling leiden, zoals Steenberghe zelf heeft mogen ervaren. Maar er is nog een reden om in de voorfase de schikkingsbereidheid af te stemmen. De balans tussen beslissen en schikken blijkt niet zelden een persoonlijke afweging te zijn. De ene rechter kan en wil graag een gesprek over belangen faciliteren, terwijl de ander daar grote moeite mee heeft. Juist dit verschil makt dat het uit het oogpunt van conflictoplossing van belang is welke zaak aan welke rechter wordt toebedeeld. En eigenlijk welke partijen aan welke rechter worden toevertrouwd. Als partijen in de voorfase aangeven of zij het wenselijk vinden dat de zitting voor het treffen van een schikking wordt benut, dan is dat informatie voor misschien wel het belangrijkste aspect van maatwerk: niet alleen de juiste rechter voor de juiste zaak, maar ook de juiste rechter voor de juiste partijen. Daar moet het wat Steenberghe betreft naartoe.

\section{Discussie}

De heer Giltay Veth (advocaat) vraagt zich af of een partij straks onaangekondigd op de comparitie als getuige gehoord zal kunnen worden. Steenberghe onderstreept dat het de rechter ook nu al vrijstaat om op de comparitie vragen te stellen aan partijen, ook als die partij zich daardoor overvallen voelt. Vooroverleg kan voorkomen dat iemand overvallen wordt.

Giltay Veth werpt tevens de vraag op wanneer partijen de gelegenheid zullen krijgen om een rechter bij hun zaak te selecteren. Bijvoorbeeld een sterke rechter als dat nodig is. Van Tongeren wijst erop dat dan een ranglijst van rechters kan ontstaan, hetgeen moet worden vermeden. De heer Gerretsen (advocaat) merkt op dat een goed advocaat juist uitzoekt wie de rechter is en zijn strategie daarop aanpast. Steenberghe benadrukt dat hij niet een keuzerecht heeft willen bepleiten. Maar rechters verschillen en het is zinvol om daar bij de verdeling van zaken rekening mee te houden.

Mevrouw Bokx-Boom (rechter en teamleider) betreurt het beeld dat rechters verschillend opereren. Het bewaken van uniformiteit zal de nodige aandacht krijgen bij de invoering van KEI. Verder brengt zij naar voren dat het procesrecht ook van toepassing is op de vele kantonzaken die jaarlijks worden afgedaan zonder bemoeienis van advocaten. In het overgrote deel van die zaken acht zij het geven van een mondeling vonnis en het horen van getuigen tijdens de mondelinge behandeling wel degelijk zinvol.

De heer Hermans (advocaat) ziet wat betreft uniformiteit een parallel met artsen, die aan de hand van protocollen borgen dat 'best practices' worden gevolgd. Dat zou een voorbeeld voor de rechtspraak moeten zijn. Het zou verder goed zijn in de aanpak meer te differentiëren naar type zaak, ook wat het bewijsrecht betreft. Steenberghe antwoordt dat er natuurlijk elementaire waarden zijn waarnaar iedere rechter moet handelen, maar dat zijn ervaring van vijftien jaar uitwijst dat onder rechters verschillend wordt gedacht over feitengaring. Een experiment heeft uitgewezen dat het voorleggen van dezelfde casus aan vier verschillende rechters tot vier volstrekt verschillende uitkomsten kan leiden, terwijl iedere rechter ervan overtuigd is dat hij heeft gedaan wat goed was.

De heer Den Tonkelaar stipt aan dat schikkingsbereidheid tijdens de zitting kan veranderen en een feilloze selectie op voorhand dus niet kan worden gemaakt. Onderzoek heeft uitgewezen dat de overtuiging van eigen gelijk tijdens de behandeling gemiddeld afneemt van 80 tot 60 procent. Een nog niet genoemd voordeel van het uitspreken van een mondeling vonnis is dat het oordeel beter kan worden uitgelegd als de rechter de betrokkene in de ogen kan kijken.

Van de Sande deelt haar ervaring dat ze recent in één week twee mondelinge uitspraken heeft gedaan, maar in twee andere zaken dan zij had verwacht. Zaken en partijen verschillen. Het is zaak goed aan te voelen wanneer mondeling uitspraak gedaan kan worden. 
Mevrouw Ahsmann is van mening dat in eenvoudige zaken mondeling uitspraak gedaan kan worden. Het is wel een bezwaar dat de feiten dan niet meer hoeven te worden opgenomen. De gronden volstaan. Dat zou in hoger beroep problematisch kunnen zijn.

De heer Heemskerk (advocaat) waarschuwt dat een voorlopige beschouwing van de zaak door de rechter ter zitting erg riskant kan zijn. Een dergelijk voorlopig oordeel is vaak op intuïtie gebaseerd. Later, na goed nadenken in alle rust, kan het heel anders blijken te liggen.

De voorzitter dankt de sprekers voor hun inleidingen en de aanwezigen voor hun komst en inbreng en sluit de vergadering. 